\title{
Strategi Pemulihan Citra Partai Politik: Kasus Partai Demokrat
}

\author{
Masduki \\ Program Studi Ilmu Komunikasi Universitas Islam Indonesia, Yogyakarta \\ Email: masadink@yahoo.co.id
}

\begin{abstract}
Academic studies and practical application of political communication strategy gained a right momentum in the current political landscape of contemporary Indonesian since the political reform in 1998. The need to build a reputation for political parties and politicians in the electoral political system requires relevant scientific devices, in the form of a communication strategy that is capable of forming and taking care of the individual and organizational image in the midst of instant culture in political practice. The strong influence of mass media is used to manipulate flow of political information in the midst of political literacy crisis among Indonesian communicity at large. This paper outlines the phenomenon of confidence crisis in the political parties, especially the Democratic Party --the party that was born in the post New Order regime. After striken by corruption cases, Democrat's position dropped and need to restore its image and reputation. In this paper, Democrat is chosen as an example because it represents the political party profiles that experienced a leap and led by Soesilo Bambang Yudhoyono, the successful president in defend his position for two periods. Borrowing image restoration theory developed by William Benoit (1995), this paper presents and analyzes the publication activities of the Democratic Party in the 2014 election that can be involved as image restoration as anti-corruption political party. This paper will also be enriched recommendations for similar action in the future.
\end{abstract}

Kata Kunci: Image, Democrat Party, Restoration, Election 2014

\section{Pendahuluan}

Secara normatif, Partai Politik berperan menjalankan fungsi artikulasi kepentingan kepentingan yang ada di dalam masyarakat dan dituntut untuk mampu mengatasi krisis internal dan eksternal yang menyerang citra positif ketika menjalankan peran tersebut. Kompetensi pengurus Parpol dalam mengelola isu-isu publik yang begitu kompleks sangat dibutuhkan untuk mengatasi permasalahan masyarakat, kemudian dialirkan pada gagasan politik kontitusional melalui parlemen dan eksekutif. Dalam kerangka mengelola isu publik, maka Parpol memerlukan kemampuan managerial public relation $(P R)$.

Aktifitas PR Partai Politik dibangun melalui kesadaran kolektif kader dan pimpinan pentingnya reputasi partai, diiringi pemahaman penuh bahwa reputasi akan selalu berkorelasi dengan usaha partai membangun kredibilitas (credibility) di masyarakat, program-program yang ditawarkan partai bisa dipercaya (realibility), mampu menjaga amanah publik sehingga layak dipercaya (trustworhtiness), serta siap bertanggungjawab (responsibility) atas resiko yang timbul. Dalam pembentukan citra, dalam membangun reputasinya, sebuah parpol tidak bisa melepaskan diri dari media massa. Salah satu best practices aktifitas merawat citra dan reputasi Parpol yang melibatkan media dalam iklim politik Indonesia pada 10 tahun terakhir adalah pencitraan politik (political branding). Sistem pemilihan langsung pada Pemilu legislatif dan Pemilu Presiden memaksa semua elemen politik memasuki 'dunia industrial' politik dengan mengadopsi platfom kerja pemasaran politik.

Dalam komunikasi politik sebagaimana dirumuskan Brian McNair, diskursus terkait alokasi sumber daya politik baik formal (eksekutif, legislatif dan yudikatif) maupun informal 
(politik alokasi sumber daya milik publik sehari-hari), tidak lagi menjadi milik politisi dan pengelola lembaga negara/pemerintahan, akan tetapi menjadi milik publik dan harus selalu dikontestasikan sejalan dengan prinsip demokratisasi (McNair, 2003).

Pencitraan menjadi kata yang jamak diungkapkan oleh praktisi politik dan analis ketika memberikan analisis terhadap kinerja Presiden Soesilo Bambang Yudhoyono dalam dua periode jabatannya. Selama 10 tahun menjadi presiden, SBY dikenal dengan sosok yang sangat menjaga penampilan dan gaya berkomunikasi, ditopang oleh tim yang bekerja untuk mengelola citra SBY di depan media dalam dan luar negeri. Langkah ini dengan berbagai kontroversi yang mengiringinya, terbukti ampuh menjaga citra SBY sebagai presiden yang peduli rakyat dan mampu mempertahankan loyalitas pemilih Partai Demokrat, Parpol yang menopang rezim mantan jenderal itu hingga tuntas tahun 2014.

Partai Demokrat resmi berdiri 9 September 2001 yang didorong atas inisiatif SBY yang terilhami oleh kekalahan SBY pada pemilihan Calon wakil Presiden dalam Sidang MPR tahun 2001. Dari perolehan suara dalam pemilihan Cawapres yang menunjukkan popularitas dirinya, maka SBY didorong oleh beberapa tokoh untuk menjadi tidak hanya Wakil Presiden tetapi menjadi Presiden. Untuk mencapainya, jalan terbaik mendirikan partai politik. Sebagai pendatang baru pasca reformasi 1998, partai Demokrat tergolong cepat berkembang dan meroket dalam perolehan suara, terutama ditopang oleh figur SBY.

Menjelang akhir masa jabatan presiden, terutama memasuki musim Pemilu 2014, langkah pencitraan juga dilakukan oleh SBY beserta Partai Demokrat. Posisi sebagai ketua umum Partai Demokrat membuat SBY harus bekerja lebih keras, karena sepanjang 2009-2014, partai ini didera dua kasus korupsi besar, yaitu kasus korupsi pembangunan Wisma Atlit di Palembang dan korupsi Hambalang yang menyeret pengurus partai yaitu Nazaruddin, Angelina Sondakh, Andi Malarangeng dan ketua umum Partai Demokrat sebelumnya, Anas Urbaningrum. Skandal ini sangat mempengaruhi elektabilitas partai. Inilah situasi kritis bagi Partai Demokrat yang notabene pemenang Pemilu dua kali: 2004 dan 2009.

Langkah 'bersolek' adalah pilihan jalan pintas yang dilakukan partai politik manapun apalagi Partai Demokrat, untuk mempertahankan prestasi juara Pemilu 2009 dan atau paling tidak mempertahankan pada posisi 3 besar pemenang Pemilu. Pada Pemilu 2014, salah satu cara yang dilakukan Partai Demokrat untuk memulihkan kepercayaan dan citra partai dengan mamasang iklan di televisi dan luar ruang (outdoor), membentuk opini publik yang lebih luas untuk membangun citra baru (image rebranding) sebagai partai bersih. Menariknya, SBY terjun langsung menjadi ikon pencitraan ini ke tengah publik.

Direktur Eksekutif Polcomm Heri Budianto seperti diberitakan portal online Merdeka, merilis survei yang menyimpulkan Partai Demokrat paling banyak diberitakan terkait krisis kepercayaan publik yakni persentase 34,2 persen. Hal tersebut dikarenakan kasus korupsi yang menimpa para kader Demokrat (Merdeka Online 9 Februari 2014). Demokrat kemudian disusul oleh partai Golkar dengan 24,3 persen karena kasus yang hampir serupa yakni korupsi. PKS dengan 20,3 persen juga diterpa pemberitaan kasus korupsi, kemudian PDIP 9,2 persen, Nasdem 5 persen dikarenakan konflik internal. Survei ini juga merekomendasikan, faktor yang dianggap publik mampu mengembalikan kepercayaan terhadap partai politik adalah tidak melakukan korupsi $(41,7)$, pro rakyat $(24,1)$, dekat dengan rakyat $(14,2)$, kualitas kader $(6,9)$, dan lain-lain $(13,1)$. Responden survei menyatakan bahwa kader dan Parpol harus memiliki kedekatan religius kepada Tuhan, mampu mewujudkan janji-janji politik, serta tidak menjadikan rakyat sebagai komoditas politik semata.

Dalam tempo yang sangat singkat, kurang dari satu tahun, mustahil Partai Politik mamu memberikan jawaban atas permintaan publik diatas. Sehingga sgtrategi komunikasi politik instan menjadi pilihan kebijakan. Tulisan pendek ini ingin menjawab pertanyaan utama, bagaimana strategi komunikasi politik yang ditempuh Parpol terutama Partai Demokrat, yang masuk dalam kategori pencitraan di media selama musim Pemilu 2014. Menggunakan teori 
strategi pemulihan citra yang dikembangkan oleh William Benoit, tulisan ini mengupas bentuk aktifitas pencitraan oleh Partai Demokrat, melalui poster, iklan dan baliho di ruang publik selama musim kampanye Pemilu 2014. Kajian ini mempergunakan data berupa iklan televisi dan luar ruang serta aktifitas Parpol yang diamati secara sekilas dan dianalisis dengan mengkorelasikannya pada konsepsi pemulihan citra.

\section{Politik Pencitraan Parpol}

Secara umum, citra adalah total persepsi terhadap suatu objek, yang dibentuk dengan memproses informasi dari berbagai sumber setiap waktu. Kamus Webster mendefinisikan citra sebagai gambaran mental atau konsep tentang sesuatu obyek. Sementara Kotler (2005) mendefinisikan citra sebagai jumlah dari keyakinan, gambaran, dan esan yang dimiliki seseorang pada suatu obyek. Obyek yang dimaksud bisa berupa orang, organisasi, kelompok orang, atau yang lainnya. Merujuk budaya masyarakat, terdapat dua bentuk sederhana dari citra, yaitu citra yang baik dan citra yang buruk. Citra yang baik dalam suatu transaksi ekonomi dan politik, merupakan aset yang sangat berharga, karena ia bisa membangun dan membantu pilihan persepsi khalayak atas suatu produk.

Frank Jefkins (1992:17) menyebutkan adanya lima jenis citra, yaitu: (1) Mirror image (citra bayangan). Citra ini melekat pada orang dalam atau anggota-anggota organisasi (biasanya adalah pemimpinnya) mengenai anggapan pihak luar tentang organisasinya. Dalam kalimat lain, citra bayangan adalah citra yang dianut oleh orang dalam mengenai pandangan luar, terhadap organisasinya. Citra ini seringkali tidak tepat, bahkan hanya sekedar ilusi, sebagai akibat dari tidak memadainya informasi, pengetahuan ataupun pemahaman yang dimiliki oleh kalangan dalam organisasi itu mengenai pendapat atau pandangan pihak-pihak luar. (2) Current image (citra yang berlaku). Suatu citra atau pandangan yang dianut pihak luar atas suatu organisasi dan individu, yang ditentukan oleh banyak-sedikitnya informasi yang mereka terima, dikonstruksi oleh mereka dan dipercayai.

Selanjutnya, (3) Multiple image (citra majemuk), yaitu adanya image yang bermacammacam dari publik terhadap organisasi tertentu yang ditimbulkan oleh mereka yang mewakili organisasi dengan tingkah laku yang berbeda-beda atau tidak seirama dengan tujuan atau asas

organisasi. (4) Corporate image (citra perusahaan), citra dari organisasi secara keseluruhan, bukan sekedar citra atas produk dan pelayanannya. (5) Wish image (citra yang di harapkan). Suatu citra yang diinginkan pihak manajemen atau suatu organisasi. Citra yang diharapkan biasanya dirumuskan dan diterapkan untuk gagasan atau merek yang baru, ketika khalayak belum memiliki informasi yang memadai mengenainya. Citra harapan ini bisa merupakan ciptaan baru atau transformasi dari citra lama yang dinilai kadaluarsa.

Skandal korupsi kader dan petinggi Parpol seperti Demokrat selama 10 tahun terakhir terbukti merusak citra partai yang bersangkutan dan menurunkan elektabilitas dari publik. Berbagai survei menyebutkan, ada penurunan tingkat kepercayaan masyarakat pada partai politik. Banyaknya kasus korupsi yang menimpa elit Parpol membuat rakyat skeptis. Adapun perbandingan kasus korupsi di Parpol hingga 2013 adalah: PDIP tertinggi (84 kasus), Partai Golkar (60), PAN (36), Demokrat (30) dan PPP (13). Menurunnya tingkat kepercayaan terhadap Parpol dapat dilacak dari partisipasi dalam Pemilu yang setiap periode justru kian semakin rendah. Sebagai illustrasi, jika angka golongan putih pada Pemilu tahun 1977: 8.40 \%, 1982: 8.53 \%, maka tahun 1999: 10.21\%, dan tahun 2009: 39.1\%.

Dalam sistem politik elektoral terbuka pasca reformasi, upaya menjaga kredibilitas Parpol melalui citra yang positif sangat penting namun pada prakteknya tidak mudah bahkan kerapkali kontradiktif. Publik masih ingat ketika awal tahun 2009 rakyat disuguhi iklan Partai Demokrat di televisi sebagai Parpol anti korupsi dan siap memberantas korupsi. Namun, fakta di lapangan terbukti sebaliknya. Semua bintang iklan dalam iklan itu terseret korupsi. Mulai Ketua Umum Anas Urbaningrum, Andi Mallaranggeng, M. Nazaruddin, hingga Angelina Sondakh. 
Mayoritas publik langsung memvonis iklan Partai Demokrat "isapan jempol", mengusung jargon anti korupsi, tetapi justru lumbung korupsi.

Dibandingkan kondisi krisis di Partai Golkar dan PDIP, partai Demokrat tergolong lebih parah. Dalam situasi tersebut, penyelamatan citra Partai Demokrat di benak publik mutlak diupayakan, menggunakan seluruh media publik yang tersedia. Komunikasi politik dilakukan dengan menempuh strategi membangun citra harapan (wish image) sehingga sikap publik tetap loyal. Sebelum menempuh komunikasi politik yang mengacu kepada citra harapan, Partai Demokrat harus memilih strategi pemulihan citra yang sudah rusak, mengacu konsep yang ditawarkan William Benoit dalam tulisan ini.

Dalam kerangka komunikasi politik untuk membangun dan memulihkan citra sebagai Parpol bersih dan pro-rakyat, Partai Demokrat memaksimalkan dua elemen sumber daya, yaitu personalitas SBY sebagai presiden yang berprestasi, dan kisah sukses kinerja SBY selaku representasi Partai Demokrat. Penggunaan SBY ini identik dengan personal branding. Yakni, sebuah pencitraan pribadi yang mewakili serangkaian keahlian, ide, sistem kepercayaan, dan persamaan nilai yang dianggap menarik oleh orang lain. Partai Demokrat 'menjual' brand SBY sebagai figur yang terbukti sukses bertahan dua periode sebagai Presiden, sebagai upaya menandingi persepsi korupsi yang sangat kuat.

Tidak hanya berposisi sebagai ikon simbolik, SBY juga terjun menjadi komunikator politik yang aktif berbicara di arena kampanye Pemilu. Komunikator politik adalah orang yang melakukan komunikasi dalam konteks politik kapanpun dan di manapun pesan politik disampaikan (Tabroni, 2012:41). Dan Nimmo membedakan antara tipe politikus ideolog dan politikus partisan dan kemudian mengkategorisasikan tiga jenis aktor komunikasi politik: yaitu politikus (pols), komunikator profesional (pross)dan aktivis (vois) (Nimmo, 2001). SBY tergolong pada kategori pertama. Penggunaan figur SBY yang tidak hanya sebagai konseptor dan pemandu ideologis bagi partai Demokrat ini sangat berani dan cenderung beresiko mengurangi wibawa dirinya sebagai Kepala Negara. Sepanjang Pemilu 2014, SBY sebagai komunikator politik menyampaikan pesan-pesan politik baik kepada individu, kelompok, maupun saat kampanye seperti yang tercermin pada gambar berikut: .

\section{Gambar 1}

SBY Terjun Langsung Berkampanye dalam Pileg 2014

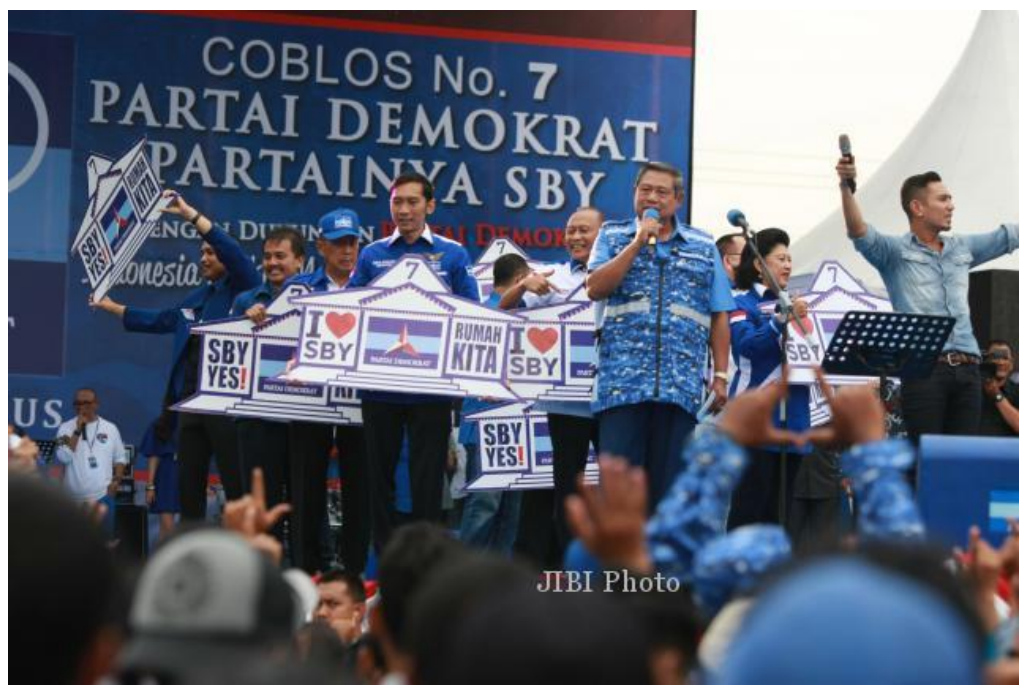

Sumber: http://www.demokrat.or.id/ , diakses 10 Juli 2014

E. Petty dan John T. Cacioppo seperti dikutip Tabroni menyebut 4 komponen yang harus ada pada komunikator politik. Pertama, kredibilitas. Semakin ahli dan dipercaya komunikator 
politik, semakin efektif pesan yang disampaikan sumber informasi. Kredibilitas ini mencakup keahlian (source expertise) dan kepercayaan (source trustworthiness). Keahlian komunikator adalah tingkat pengetahuan yang dimiliki atas subyek yang dikomunikasikan. Sedangkan kepercayaan adalah sejauh mana sumber dapat memberikan informasi yang tidak memihak dan jujur. Kedua, daya tarik komunikator. Daya tarik komunikator bisa bersumber penampilan fisik, gaya bicara, kepribadian egaliter, kehangatan, rekaman kinerja, teknik komunikasi, perilaku. Ketiga, kesamaan membangun harapan dengan khalayak.

Kesamaan kebutuhan dan perasaan menjadi penyebab suka tidaknya audience atas komunikator. Komunikator dapat berhasil menyenangkan publik karena telah membuktikan bertindak, mendukung aspirasi yang serupa dengan komunikan. Keempat, power atau posisi kekuasaan sosiologis komunikator. Komunikator yang memiliki power tertentu lebih efektif dalam menyampaikan pesan. Figur SBY setidaknya memiliki tiga komponen yang dibuat Petty diatas, yaitu kredebilitas, daya tarik dan power sebagai mantan Presiden.

\section{Strategi Pemulihan Citra}

Salah satu model konsepsi dan teori pemulihan citra yang populer adalah yang dikembangkan William Benoit sebagai image restoration theory. Benoit mengembangkan teori ini berbasis pada teori apologi dan analogi yang dikembangkan oleh Rosenfiled (1968) dan Ware and Linkugel (1970). Menurut William Benoit, pemulihan citra adalah berbagai strategi yang dapat digunakan untuk mengurangi kerusakan identitas dalam sebuah peristiwa di mana reputasi telah rusak. Pemikiran dari Benoit ini kemudian sangat aplikatif dan banyak dirujuk oleh konsultan politik di Amerika dan seluruh dunia.

Untuk meyakinkan ketajaman pemikirannya, Benoit mengambil contoh aktual strategi yang dilakukan para politisi dan selebriti ketika mendapat isu miring, seperti yang dilakukan Hugh Grant ketika dituduh terlibat prostitusi atau Ratu Elzabeth ketika mengelola isu pasca kematian tragis Lady Diana yang mengguncang kerajaaan Inggris. Pada level organisasi, Benoit juga mengambil contoh AT \& T, perusahaan telekomonikasi raksasa AS mengelola citra paska dikabarkan bangkrut tahun 1991. Skandal Presiden AS Bill Clinton dan bentuk klarifikasi yang ditempuhnya ketika dituduh berselingkuh dengan Monica Lewinsky menjadi salah satu obyek kajian Benoit yang akurat terkait restorasi citra.

Teori dan strategi pemulihan citra diterapkan baik sebagai cara memahami situasi krisis citra pribadi atau organisasi, maupun sebagai langkah taktis untuk memulihkannya. Pemikiran Benoit berpusat pada aktifitas komunikasi sebagai instrumen utama dan citra terbaik sebagai tujuan akhirnya. William Benoit, menguraikan konsepsi ini dalam bukunya Accounts, Excuse, An Apologies: A Theory of Image Restoration Strategies. Bagi Benoit, mempertahankan citra dengan kategori baik adalah tujuan utama komunikasi politik dalam Pemilu. Elemen 'wajah' visual Parpol sama penting dengan elemen individu atau organisasi dalam pencitraan ulang. Aspek persepsi merupakan sasaran dasar aktifitas pemulihan citra sehingga sebagai aktor tertuduh, Partai Politik harus memakai proaktif. Aktor baik Parpol ataupun politisi yang melakukan tindakan buruk harus pula memutuskan strategi terbaik berdasarkan situasi politik aktual di lapangan (Benoit, 1995).

Terdapat lima teori yang diperkenalkan Benoit tentang strategi pemulihan citra: Pertama, denial (penolakan adalah reaksi alami terhadap sebuah tuduhan). Maknanya adalah seseorang atau organisasi dapat menyangkal bahwa tindakan itu terjadi atau menyangkal peran mereka dalam melakukan hal itu. Ada dua model denial. Pertama, simple denial, penyangkalan sederhana, seperti ucapan kami tidak melakukan hal ini. Kedua, shifting the blame atau menyangkal perbuatan dan menggeser kesalahannya kepada orang lain dengan mengatakan: bukan kami, namun orang lain yang melakukannya.

Kedua, evading responsibility (menghindari tanggungjawab). Ketika seseorang tidak dapat menyangkal melakukan perbuatan, organisasi mungkin mencoba untuk menghindar dari 
perbuatannya sendiri. Hal tersebut bisa dikatakan sebagai lepas tanggung jawab atau menghindari tanggung jawab terhadap tindakannya tersebut. Langkah ini bertujuan untuk mengurangi tanggung jawab terhadap tindakan yang dimaksud. Pada strategi ini, Benoit mengelompokkannya menjadi beberapa varian: (1) Scapegoating (pengkambinghitaman): aktor dapat mengklaim bahwa perbuatan itu dilakukan sebagai tanggapan terhadap tindakan salah yang lain. (2) Defeasibility: aktor memohon kurangnya pengetahuan atau kontrol tentang faktorfaktor penting yang berhubungan dengan tindakan. (3) Ofensif, pihak tertuduh melakukan kesalahan karena kekurangan informasi dan kompetensi.

Dalam strategi menghindar tanggungjawab, aktor bisa membuat an excuse based on accidents (alasan berdasarkan kecelakaan), membuat alasan atas faktor-faktor di luar kendali organisasi. Aktor tidak dapat menyangkal tidak melakukan suatu kekeliruan, tetapi mengakui bahwa tindakan itu terjadi secara tidak sengaja (tidak diduga) yang disebabkan oleh keadaan yang juga tidak diduga sebelumnya. Aktor berupaya mengklarifikasi bahwa melakukan suatu kekeliruan tidak bermaksud sebagai sebuah kesalahan yang disengaja.

Ketiga, reducing offensiveness (mengurangi pertahanan). Seseorang atau organisasi berusaha untuk mengurangi tingkat persepsi negatif di benak publik. Strategi ini memiliki beberapa komponen, yaitu bolstering, mengurangi dampak negatif dengan cara menunjukkan ide positif. Seseorang atau organisasi mengingatkan publik atas perilaku baik yang pernah ia lakukan sebelumnya atau reputasi yang sebelumnya baik, mencoba meraih simpati publik dengan mengutip tindakan positif di masa lalu, tanpa mengkaitkan dengan kesalahan yang telah diperbuat hari ini. Komponen selanjutnya adalah minimization atau mengurangi opini buruk. Mencoba untuk meminimalisasi perasaan negatif terhadap hal yang terjadi dengan cara memberikan persuasi yang baik. Hal ini bertujuan untuk meyakinkan publik bahwa hal yang terjadi tak seburuk seperti yang dipikirkan. Aktor juga bisa mengembangkan metode differentiation (perbandingan), perbuatan itu dibedakan dari tindakan lebih ofensif lain untuk mengurangi perasaan negatif membandingkan dua perilaku kontradiktif.

Komponen lain yang kerapkali dipakai politisi dalam kerangka bertahan adalah aspek attacking accuser (menyerang penuduh). Aktor menyerang individu penuduh dengan cara mempertanyakan kredibilitas sumber tuduhan. Pada strategi ini aktor berharap kredibilitas penuduh rusak sehingga tuduhan akan dipertanyakan. Pada saat aktor gencar menyerang penuduhnya, perhatian publik diharapkan teralihkan. Komponen terakhir adalah pemberian kompensasi (compensation). Aktor menawarkan mengganti kerugian atau memperbaiki obyek yang rusak akibat perbuatan korupsinya. Kompensasi identik dengan penawaran dalam upaya menebus kesalahan, dengan tujuan agar tuduhan atau liputan media berakhir dan perbuatan individu atau organisasi diampuni serta reputasinya kembali.

Keempat, corrective action (tindakan korektif). Janji bahwa aktor akan memperbaiki masalah untuk mengembalikan situasi ke kondisi sebelumnya atau menjanjikan untuk membuat perubahan untuk mencegah terulangnya perbuatan serupa. Tindakan korektif adalah strategi pengembalian citra dimana pihak tertuduh berusaha untuk mengembalikan citranya dengan menjanjikan bahwa tindakan tersebut akan diperbaiki. Coombs (2006) menilai pilihan politik terhadap strategi tindakan korektif harus dibarengi ruang akses publik selaku korban untuk melakukan pengawasan yang ketat.

Kelima, mortification (sikap bertanggungjawab dan mohon maaf). Organisasi atau seseorang secara berani dan terbuka mengakui, bertanggungjawab atas perbuatannya serta meminta maaf. Benoit menyebut ini strategi penyiksaan diri. Aktor memilih untuk mengakui kesalahan dan meminta pengampunan kepada publik. Meskipun dalam teori pemulihan citra mengintrodusir strategi penggunaan penyiksaan diri dan tindakan korektif, maka organisasi atau individu disarankan memilih strategi lain terlebih dahulu. Dalam kultur politik yang rasionalistik, pilihan strategi mortification and corrective action sangat beresiko kerusakan citra 
secara permanen, karena membentuk sikap final publik yang memvonis aktor bersalah dan untuk itu tidak layak dipercaya di masa depan (Benoit, 1995).

\section{Pilihan Strategi Demokrat}

Berdasarkan uraian pemikiran Benoit diatas, maka tulisan ini mencoba menyinggung pilihan strategi pemulihan citra yang dilakukan Partai Demokrat, terutama dalam Pemilu tahun 2014 yang lalu. Strategi pemulihan citra itu diwujudkan dalam beragam aktifitas rutin dan sosial oleh organisasi dan secara simultan melibatkan publikasi melalui media massa dan media luar ruang di seluruh Indonesia. Pada saat terungkapnya kasus korupsi Hambalang dan kasus lain yang melibatkan politisi Partai Demokrat, upaya-upaya meredam gejolak citra buruk yang melanda dilakukan dengan memilih dua strategi.

Pertama, denial (penolakan dan penyangkalan). Dalam berbagai pemberitaan media, pimpinan baru Partai Demokrat mengakui sedang terjadi krisis di Partai Demokrat sebagai dampak tindak pidana korupsi Anas Urbaningrum (AU). Namun pimpinan partai Demokrat menegaskan bahwa secara organisasi, partai Demokrat tidak terlibat. Pada awal merebaknya isu korupsi, PD menyatakan meyakini Anas tidak terlibat. Kalaupun terbukti benar, maka perbuatan itu dilokalisir sebagai perilaku pribadi bukan institusi. Pimpinan Partai Demokrat di pusat dan daerah secara rutin menggelar konferensi pers untuk melakukan klarifikasi, mengelola opini publik seperti pada gambar berikut ini:

Gambar 2

Ketua Harian dan Sekjen Partai Demokrat

Melakukan Konferensi Pers di Kantor DPP PD Jakarta

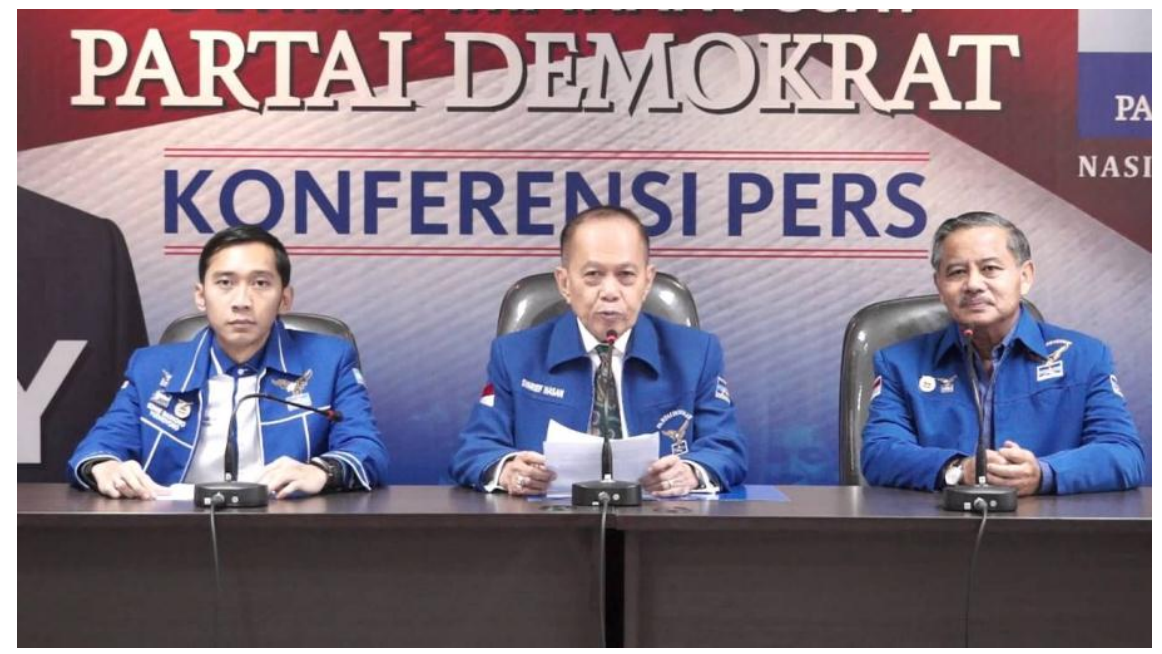

Sumber: http://www.demokrat.or.id/ , diakses 10 Juli 2014

Penolakan atau penyangkalan tindakan korupsi dilakukan tidak hanya melalui media konvensional tetapi juga melalui media virtual seperti website resmi Partai Demokrat. Dalam website tersebut tardapat berita-berita yang menolak atas tuduhan Partai Demokrat dan pada saat yang sama mengedepankan sisi positif dari Partai Demokrat, misalnya prestasi yang telah diraih Partai Demokrat melalui figur SBY. Website partai juga memberitakan pada tanggal 27 Maret 2014, SBY sebagai Ketua Umum Partai Demokrat berhasil mendapatkan prestasi penghargaan dari World Health Organization (WHO). Dalam konteks ini, Demokrat juga berupaya melakukan bolstering dan differensiasi. Demokrat menggiring ingatan publik pada kredibilitas SBY yang akan tegas menindak kader pelaku korupsi dan terbukti mampu memperkuat Komisi Pemberantasan Korupsi sebagai ikon gerakan anti korupsi. 
Dari publikasi berbagai prestasi pada website resmi Partai Demokrat menunjukkan adanya pilihan strategi denial dengan cara mengalihkan kasus yang sedang terjadi dengan pemberitaan prestasi yang diraih saat pemerintahan SBY. Selain website resmi, politisi dan Partai Demokrat secara nasional juga membuat baliho yang didalamnya terdapat pesan bahwa Partai Demokrat adalah partai politik yang bersih dan anti korupsi. Dalam upaya differensi, dalam berbagai kesempatan kampanye terbuka atau melalui media, elit Demokrat juga mencoba menggiring opini publik bahwa korupsi dapat terjadi di semua partai politik dan peringkat korupsi di Partai Demokrat tidak yang paling tinggi dibandingkan partai politik lain di Indonesia. Pesan ini bisa dicermati seperti pada baliho berikut:

\section{Gambar 3 \\ Baliho Informasi Partai Paling Korup}

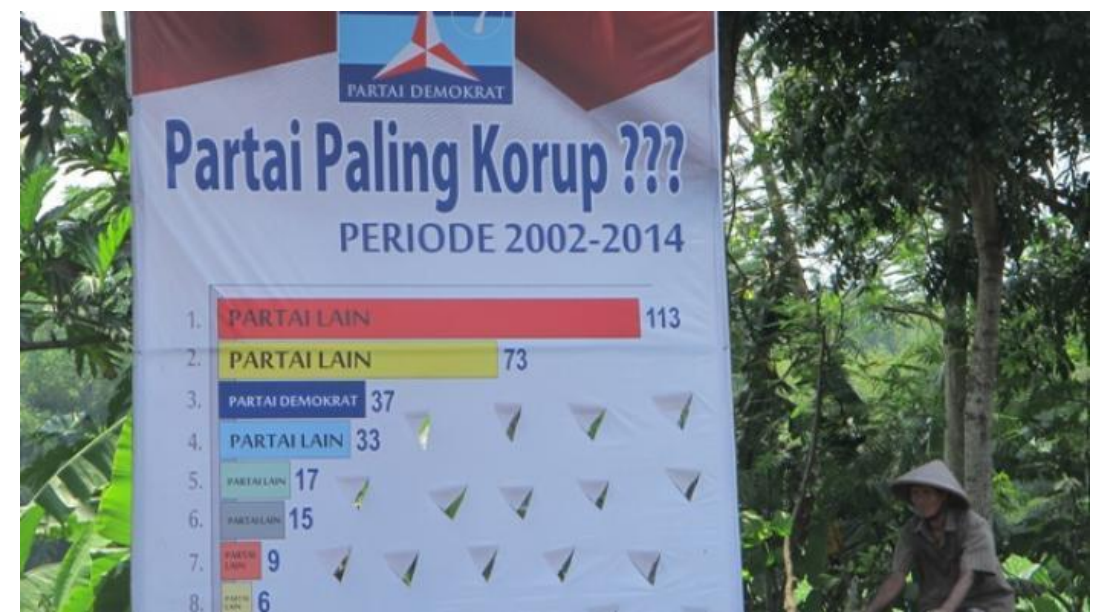

Sumber: http://www.demokrat.or.id/ , diakses 10 Juli 2014

Kedua, strategi yang ditempuh partai Demokrat, terutama ketika kasus korupsi yang melibatkan elit partai tidak bisa terbantahkan dengan mortification (sikap bertanggungjawab dan minta maaf). Partai menyampaikan permohonan maaf secara khusus kepada masyarakat oleh apa yang telah diperbuat oleh kader yang sedang tersangkut kasus, namun diberikan penegasan bahwa bukan hanya Partai Demokrat yang pernah tersangkut kasus korupsi, banyak partai politik lain yang juga melakukan korupsi. Partai Demokrat meminta maaf kepada publik melalui media dan ditindaklanjuti dengan kegiatan sosial pemberian bantuan Sembako oleh partai dan para politisi yang bertarung dalam Pemilu legislatif. Strategi ini merupakan pilihan terpahit yang ditempuh, bahkan langsung diutarakan SBY selaku Ketua Dewan Pembina PD kepada publik melalui jumpa pers. Strategi ini diikuti dengan tindakan koreksi melalui dorongan agar kasus Anas segera dituntaskan.

Langkah pemberian bantuan Sembako yang kemudian dilakukan para calon anggota legislatif dari partai Demokrat, identik dengan strategi corrective action, suatu upaya karitatif dalam memperbaiki kerusakan citra. Menurut kajian psikologi politik mayoritas pemilih di Indonesia, ketika seseorang atau sebuah organisasi melakukan kesalahan, maka yang harus dilakukan secara kultural sehingga membentuk simpati adalah kesediaan mengoreksi dan bertanggung jawab atas kesalahan itu. Tindakan korektif yang dilakukan Demokrat mayoritas meliputi program-program pro rakyat yang bertujuan untuk menanggulangi kemiskinan pada masyarakat yang kurang mampu dan mendekatkan partai pada publik, melalui pemberian beras untuk keluarga miskin dan Program bantuan siswa miskin (BSM).

Dengan mengambil resiko dituduh melakukan praktek politik uang (money politics), aksi pemberian Bantuan Siswa Miskin (BSM) oleh SBY dan Demokrat adalah bantuan yang 
diberikan kepada siswa keluarga kurang mampu agar bisa melakukan kegiatan belajar di sekolah. Bantuan ini memberi peluang bagi siswa untuk mengikuti pendidikan di level yang lebih tinggi. Selain itu BSM ini juga bertujuan mengurangi jumlah siswa putus sekolah akibat permasalahan biaya pendidikan di Indonesia. Karakter program BSM yang bersifat tunai dan menyentuh problem dasar kebutuhan publik terbukti efektif memberi efek pencitraan bagi pihak pemberi bantuan termasuk partai Demokrat. Di tengah ketidakpastian pulihnya citra, dalam perolehan suara pada Pemilu legislatif tahun 2014, Demokrat masih mampu meraup suara diatas 10 persen dan bertengger pada posisi menengah.

\section{Gambar 4}

AKsi Pemberian Bantuan Sembako oleh Caleg PD

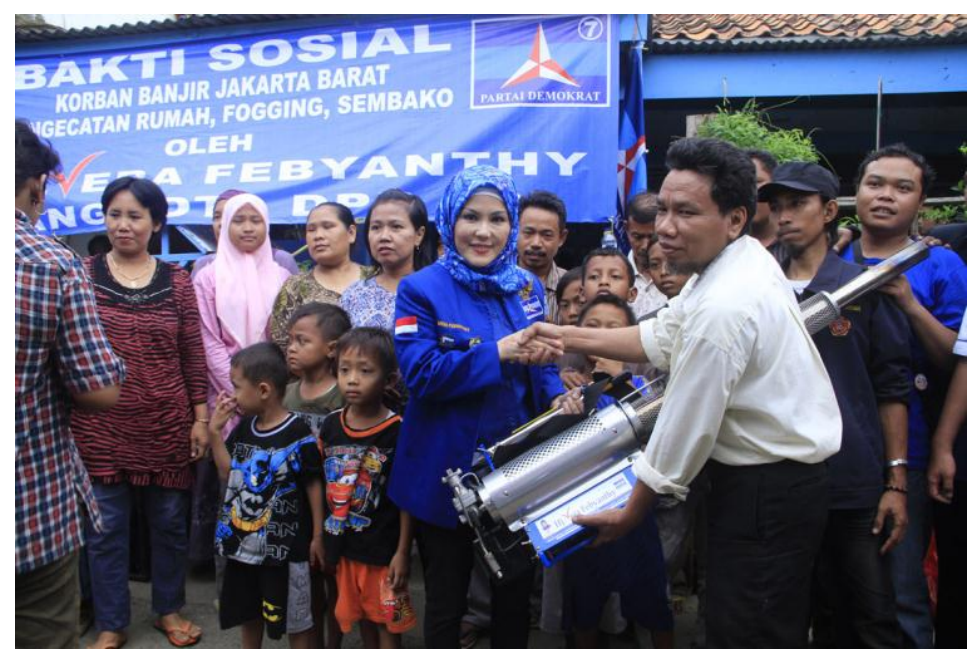

Sumber: http://www.demokrat.or.id/ , diakses 10 Juli 2014

\section{Penutup}

Merujuk konsepsi pemulihan citra yang dikembangkan Wiliam Benoit, maka dapat disimpulkan bahwa Partai Demokrat dalam Pemilu 2014 menempuh sedikitnya tiga strategi pemulihan. Yaitu ketika pada awal kasus korupsi menggema di media, elit politisi partai menerapkan strategi denial dengan membantah terjadinya korupsi. Dalam perkembangan ketika kasus yang melibatkan petinggi partai ini semakin terbukti dan diyakini publik, strategi yang dipilih bergerak ke pengakuan dan kemudian permintaan maaf terbuka kepada publik. Strategi ini dilengkapi dengan tindakan koreksi. Perubahan strategi ini berdampak buruk pada persepsi publik bahwa Demokrat tidak konsisten dan pada muaranya membuat posisi sebagai pemenang Pemilu harus diserahkan ke PDIP dalam Pemilu 2014. Citra menjadi lebih buruk karena tidak adanya korelasi dan klarifikasi yang memadai di benak publik antara jargon anti korupsi dengan tindakan serius memberantas korupsi oleh SBY.

Mengutip pendapat pakar pemasaran Hermawan Kertajaya, elemen-elemen yang biasanya dipergunakan dalam komunikasi pemasaran dan bisnis telah dipergunakan pula dalam pemasaran politik. Istilah positioning, differensiasi dan brand (PDB) telah dibuat semenarik mungkin dan ditujukan secara tepat kepada pemilih yang diposisikan sebagai konsumen produk politik. Bahkan di era gelombang ekonomi dan politik baru (new wave) yang berbasis media sosial, PDB tidak cukup. Diperlukan C3, yaitu clarification, codification and character. Segala opini dan pencitraan verbal yang dibangun dengan manajemen public relations yang profesional oleh suatu tokoh politik atau partai politik, pasti tidak akan mampu membangun citra tanpa strategi yang kuat untuk menancapkan kepercayaan (trush) melalui tindakan konkret yang dapat 
mengklarifikasi publik bahwa suatu Parpol atau politisi itu kredibel, bisa dipercaya (Kertajaya dalam Wulandari, 2014).

Lebih jauh, belajar dari partai Demokrat, dalam proses pemulihan citra, peran media massa sangat penting. Pilihan apapun akan beresiko terhadap citra diri Partai Politik. Segala upaya pencitraan yang ditawarkan William Benoit tidak otomatis membentuk persepsi baru dari benak publik, jika sifatnya hanya sesaat dan berjangka pendek. Pengaruh media dengan kebebasan redaksi yang tinggi membuat aksi pencitraan tidak selalu akurat karena media memiliki agenda setting tersendiri dalam ruang redaksi (newsroom). Dalam iklim politik Indonesia kontemporer, bagi Partai Demokrat ataupun partai politik lain, yang diperlukan adalah pengembangan sistem imun atas malpraktek kader dan elit Parpol di semua lini yang akan berkorelasi dengan citra positif jangka panjang.

\section{DAFTAR PUSTAKA}

Benoit, William. (1995). Accounts, Excuses, and Apologies: A Theory of Image Restoration Strategies. New York: State University of New York Press.

Coombs, W. T. (2006). Crisis Management: A communicative approach. USA: Botan \& Hazleton

Jefkins, Frank (1992). Public Relations. Bandung: PT. Citra Aditya Bakti.

Kotler, Philip \& Gary Amstrong. (2008). Prinsip Prinsip Pemasaran. Jakarta: Penerbit Erlangga.

McNair, Brian. (2003). An Introduction to Political Communication, ed. $3^{\text {rd }}$, London: Routledge.

Nimmo, Dan (2001). Komunikasi Politik Khalayak dan Effek, Bandung: Remaja Rosdakaryza

Tabroni, Roni (2012). Komunikasi Politik Di Era Multimedia, Bandung: Simbiosa Rekatama

Wulandari, Retno. (2014). Media Darling, Jakarta: Gramedia Pustaka Utama

http://www.demokrat.or.id/ , diakses 10 Juli 2014

http://www.merdeka.com/pemilu-2014/survei-demokrat-paling-krisis-karena-korupsi.html, diakses 14 Juli 2014 